Vietnam Journal of Earth Sciences, 39(3), 225-239, DOI: 10.15625/0866-7187/39/3/10268

Vietnam Academy of Science and Technology
(VAST) Vietnam Journal of Earth Sciences
http://www.vjs.ac.vn/index.php/jse

\title{
Abnormal features of oceanographic characteristics in upwelling Vietnam waters under impact of El Niño events
}

Tong Phuoc Hoang Son*1, Tran Van Chung1, Nguyen Huu Huan¹, Ngo Manh Tien¹, Vu Van Tac', Nguyen Hoang Thai Khang', Nguyen Truong Thanh Hoi ${ }^{1}$, Marine Herrmann², Eko Siswanto ${ }^{3}$

${ }^{1}$ Institute of Oceanography, Vietnam Academy of Science and Technology

${ }^{2}$ LEGOS, IRD-CNES-CNRS-Université de Toulouse, University of Sciences and Technology of Hanoi, Vietnam Academy of Science and Technology

${ }^{3}$ Japan Agency for Marine-Earth Science and Technology (JAMSTEC)

Received 28 March 2017. Accepted 5 June 2017

\begin{abstract}
The summer upwelling that occurs in coastal waters of South Central Vietnam is one of the major hydrographic features in the East Sea. A weakening of the upwelling after major El Niño events was observed in the literature for previous El Niño events and was verified here from the analysis of new satellite image data sets of sea surface temperature (SST) and surface wind. The analysis of empirical orthogonal function (EOF) from of monthly SST as well as of temporal and spatial variations of SST and wind force allow us to identify abnormal characteristics in ocean surface water that happened after El Niño episode, in agreement with previous studies. Those abnormal characteristics in Vietnam upwelling waters appeared mainly during the summers of 1998, 2003, 2010 and 2016 years for the El Niño decline phase. The upwelling weakening during El Niño decline episodes is associated with the following signals: (1) Wind force and Ekman pump are very weak; (2) the cold and high chlorophyll-a tongue is shifted northward but not extended eastward; (3) for years when El Niño occurs, SST strongly increases and reaches a peak in May or early June of next year, during the declining phase of El Niño episode; (4) upwelling phenomenon typically occurs during August and not July. Using a reanalysis dataset derived from the HYCOM/NCODA system coupled with a local Finite Element Model (FEM) allow us to complete our knowledge about the abnormal oceanographic characteristics of deeper water layers after El Niño episodes. The analysis of spatial variations of oceanography fields derived from HYCOM/NCODA/FEM system along zonal and meridional sections and vertical profiles as well as the results obtained from water mass analysis allow us to identify in details the abnormal oceanic characteristics of deeper water layers during the declining El Niño phase. Those are; (5) Sea water in both surface and deeper water layers were transported dominantly northward but not eastward; (6) The thermo-halocline layer in South Vietnam upwelling center was deeper (about 90 - 100m), compared with previous El Niño and normal years (50-60 m and 35-40 m, respectively); (7) Extreme global warming in recent years (2012-2016) pressed the thermo-halocline layer in upwelling center deeper (90-100 m) during summer. Under the influence of the ocean global warming, this process should progress continuously, the depth of thermo-halocline layer should become therefore deeper and deeper in next years.
\end{abstract}

Keywords: Weakening of Vietnam waters Upwelling, ENSO, El Niño decline phase, oceanographic characteristics anomalies.

(C)2017 Vietnam Academy of Science and Technology

\section{Introduction}

The upwelling is defined as an upward

Corresponding author, tongphuochoangson@gmail.com movement of seawater towards the surface. As upwelled water carries a large amount of nutrients from the lower layer to the upper and surface layers, upwelling regions are therefore 
Tong Phuoc Hoang Son, et al./Vietnam Journal of Earth Sciences 39 (2017)

considered to be important fishing areas (Hale et al., 2005). Vietnam coastal upwelling water is one of the major hydrographic features of the East Sea (ES) and was studied by many authors (Wirtky, 1961; Le Phuoc Trinh and others, 1981; Vo Van Lanh et al., 1995; Tong Phuoc Hoang Son et al., 2005; Barthel et al., 2009; Dippner and Loick-Wilde, 2011, and so on). The water circulation in Vietnam coastal upwelling is strongly influenced by the monsoon regime (Ose et al., 1997). The center upwelling of cold waters moves southward from $15^{\circ} \mathrm{N}$ in May to $11^{\circ} \mathrm{N}$ in August with a changing of its scale. It finally evolves into a cold jet stretching offshore in mid-August (Kuo et al., 2000; Xia et al., 2003). In this period, the coastal water circulation is dominated by the presence of a cold water tongue extending offshore and evolving as a cold jet stretching eastward along $11^{\circ} \mathrm{N}$, under the influence of the South-East monsoon (Pohlmann, 1987; Shaw and Chao, 1994; Kuo et al., 2000). This circulation is strongly related to the summer upwelling that results in a cooling of surface water off South Vietnam associated with a sea surface temperature (SST) decrease of more than $1^{\circ} \mathrm{C}$ (Wyrtki 1961; Huang et al., 1994; Kuo et al., 2000; Tang et al, 2004). SST in this cold jet is below $26^{\circ} \mathrm{C}$ (Xie et al., 2003; Kuo et al., 2000). Based on the analysis of sea surface height (SSH) derived from satellite altimetry data, Xie et al. (2007) concluded that the SSH field shows a dipole structure, positive in the northern and negative in the southern basin with a nodal line around $11^{\circ} \mathrm{N}$. This SSH features in the Vietnam upwelling water represent a marked weakening of the climatologically anticyclonic circulation there, acting to favor the cold jet eastward-stretching for normal years when El Niño event does not occur (Xie et al., 2003). A northward shift of the anti-cyclonic eddy was observed in summer 1998 (Xie et al., 2007), as well as 2010 (Tran Van Chung, Bui Hong Long, 2016) when the ES was anomalously warm, making them the warmest summers on record in this region (Wang et al., 2002, NOAA, 2011). In another aspect, sea surface temperature anomaly (SSTA) is recognized as an index for the Asian monsoon and El Niño - South Oscillation (ENSO) system (Ose et al., 1997). SST in the ES increases during the El Niño developing phase and peaks in the following summer during El Niño declining phase (Qu et al., 2004). The appearance of SST anomalies happened during El Niño declining periods (i.e summer of 1998, 2003) with an extreme increasing of SST in upwelling waters as well as a northward moving of the cold upwelling center (Xie et al., 2007). On the contrary, during the mature El Niño periods (i.e summer 1997, 2002) and normal summers, cold water jet extended eastward. A Recent result of Siswanto and his colleagues (Siswanto et al., 2017) also emphasized and divided the impact of El-Niño in ES into 3 different periods: developing, mature, and weakening phases. The oceanic anomalies in ES were mainly observed during the ElNiño weakening phase. Most of the studies on these oceanic anomalies mainly focused on the analysis of spatiotemporal variations of surface oceanographic variables. However, very few works studied into details the anomalies associated with El Niño of oceanography structures in ES for deep water layers. The present study aims to understand, consolidate and clarify our knowledge of the main El Niño induced oceanographic anomalies in both surface water as well as deeper layers in Vietnam coastal upwelling waters.

\section{Study area and used data}

\subsection{Description of study area}

The studied area is the Vietnam coastal upwelling water region, between longitude $107^{\circ} 30^{\prime}$ to $112^{\circ} 00^{\prime} \mathrm{E}$ and latitude $10^{\circ} 30^{\prime}$ to $14^{\circ} 00^{\prime} \mathrm{N}$. The studied area is shown in Figure 1. 


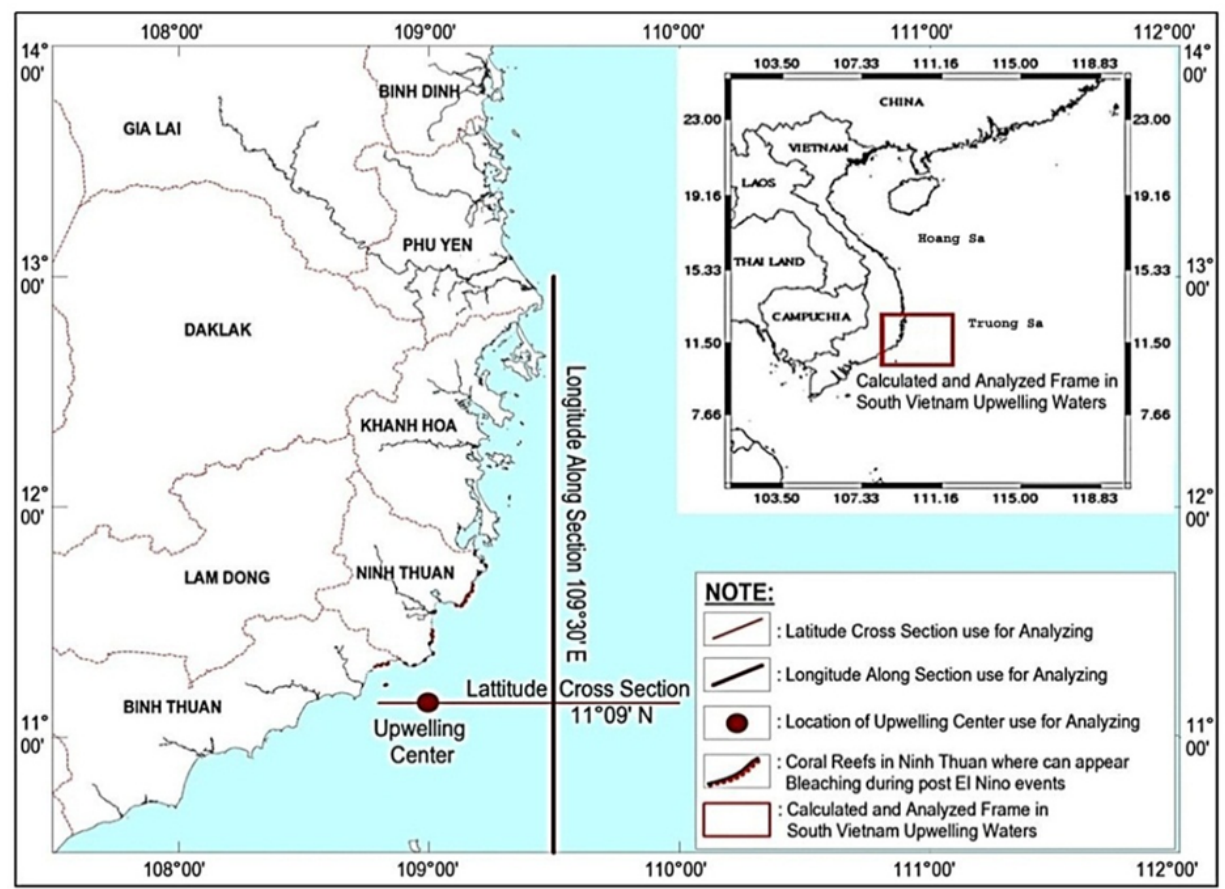

Figure 1. Studied region focusing on Vietnam upwelling waters and frame of computation (red box) combined with longitude and latitude sections (red and brown lines) and location of upwelling center (brown circle) for analysis. Time series of data are analyzed from 1997 to 2016

\subsection{Used data}

We use several datasets: the monthly averaged MODerate Resolution Imaging Spectroradiometer (MODIS) SST products; assimilation data obtained from (i) the wind dataset of National Centers for Environmental Prediction (NDCP) and (ii) datasets of the Hybrid Coordinate Ocean Model (HYCOM) run on the base of the Navy Coupled Ocean Data Assimilation (NCODA) coupled running with local numerical modeling. Data analysis is performed on the period of 1997-2016.

\section{SST Datasets}

Satellite remote sensing observations from the NASA MODIS instrument can be used to derive SST. Level-3 monthly mean MODIS SST products between July 2002 and December 2016 were obtained from https://giovanni.gsfc.nasa.gov/giovanni/.

\section{NCEP datasets}

Wind dataset (from 1997 to 2016) from Climate Forecast System Reanalysis (CFSR) of National Centers for Environmental Prediction (NCEP) was used for assessing the Wind Stress Curl (WSC).

Optimum Interpolation Sea Surface Temperature (OISST) of NCEP derived from a combination of the Advanced Very High Resolution Radiometer (AVHRR) and Advanced Microwave Scanning Radiometer of the Earth Observing System (AMSR-E) with a spatial resolution $0.2^{\circ}$ was used to provide monthly SST. NCEP datasets were obtained from NOAA website (https://www.esrl.noaa.gov/psd/data/gridded/d ata.ncep.reanalysis.html). 
Tong Phuoc Hoang Son, et al./Vietnam Journal of Earth Sciences 39 (2017)

The HYCOM/NCODA reanalysis - assimilation dataset

The GLBa0.08_rect product obtained from the HYCOM/NCODA global $1 / 12^{\circ}$ reanalysis - assimilation system provided us datasets of temperature, salinity, and meridional and zonal currents for 32 different water layers. They were obtained from the HYCOM website (http://www.hycom.org/dataserver/glb.analysis)

\section{The Oceanic Niño Index (ONI)}

ONI is used indices to define El Niño and La Niña events. The ONI uses a 3-month running SST mean, and to be classified as El Niño or La Niña, the anomalies must exceed $+0.5^{\circ} \mathrm{C}$ or $-0.5^{\circ} \mathrm{C}$ for at least five consecutive months.

\subsection{Methodology}

\section{Empirical Orthogonal Function - EOF analysis}

Statistical method based on Empirical Orthogonal Function - EOF were used to differentiate the seasonal and inter-annual variations of SST. EOF is a statistical method used to decompose the variability of a field into sums of modes, each of them being described as a spatial pattern and a time series (Wang and An, 2005). To derive the variability of SST on an inter-annual timescale, 13-month running means were used to filter out the annual variation and seasonal variability. EOF analysis was used to examine the spatial patterns and temporal evolution of the dominant modes of SST for seasonal or inter-annual timescales.

Estimation of upwelling generated force from wind data

Ekman transport is an essential component of ocean circulation in coastal upwelling regimes. Ekman transport describes the wind-driven portion of circulation seen in the surface layer and is induced by the Wind Stress Curl (WSC) (Colling, 2001; Knauss, 2005). In North Hemisphere, when WSC $>0$,
Ekman pumping is strong and upwelling phenomena occurs, contrarily when WSC $<=0$, Ekman pumping is weak and/or Ekman suction with downwelling phenomena appears (Sverdrup et al., 1942). Wind Stress Curl (WSC) was computed using the following formula:

$$
\text { where: } \quad \tau_{\text {Wind }}=\rho_{\text {air. }} . \mathrm{C}_{\text {D. }} \mathrm{U}_{10}{ }^{2}
$$

$$
W S C=\frac{\partial}{\partial x}\left(\frac{\tau^{y}}{\rho f}\right)-\frac{\partial}{\partial y}\left(\frac{\tau^{x}}{\rho f}\right)
$$

$C_{D}$ is the wind drag coefficient, $U_{10}$ is the wind velocity at $10 \mathrm{~m}$ height; $\tau^{x}, \tau^{y}$ are the $\mathrm{x}$ and y- wind stress $\tau$ components; $\rho$ is the water sea density, $f$ is the Coriolis force.

Extraction of the oceanic parameters from HYCOM/NCODA/FEM

We used the predicted "Ocean Weather" data obtained from the Hybrid Coordinate Ocean Model (HYCOM) run on the base of the Navy Coupled Ocean Data Assimilation (NCODA). The HYCOM system represents the world's first eddy-resolving global ocean prediction system with both high horizontal $\left(1 / 12.5^{\circ}\right)$ and high vertical (32 deep layers) resolution. It is therefore eddy-resolving. Due to its resolution, the HYCOM/NCODA system can however not represent submesoscale oceanic processes (such as the effects of tidal current, land-atmospheric-ocean interactions, the effects of complex shorelines, relief of shallow water, and so on). The local hydrodynamical Finite Element Model (FEM) for upwelling region of South Vietnam described in Bui Hong Long and Tran Van Chung (2009) was therefore applied and combined with HYCOM/NCODA to provide a high resolution modeled dataset over the studied area. The HYCOM-NCODA-FEM outputs including sea water temperature, salinity, and meridional/zonal current in twenty-two layers $(0,2$, $4,6,8,10,12,15,20,25,30,35,40,45,50$, $60,70,80,90,100,150$, and $200 \mathrm{~m}$ ) were extracted and used for the analysis. Flow chart of coupled HYCOM-NCODA-FEM for forecasting the oceanic structures in upwelling waters of Central Vietnam Sea is shown in Figure 2. 
Vietnam Journal of Earth Sciences, 39(3), 225-239

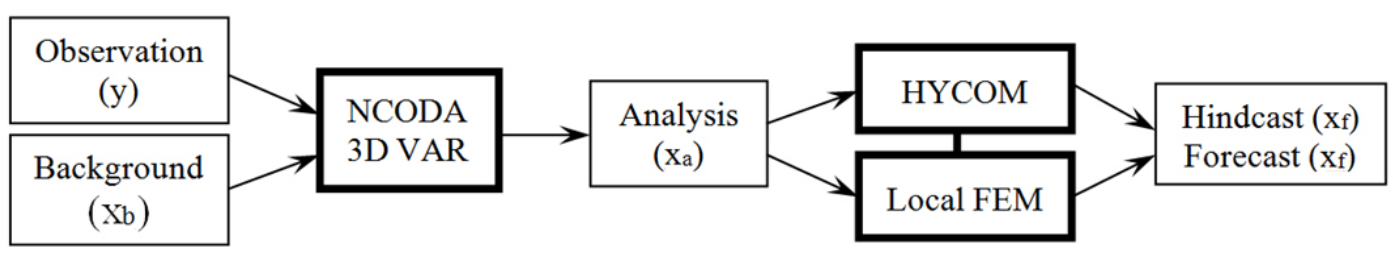

Figure 2. Flow chart of coupled HYCOM-NCODA-FEM for hindcast/forecast of the oceanic structures in the upwelling region of South Vietnam Sea

\subsection{Results and discussion}

\subsubsection{Seasonal SST variability from EOF analysis}

The EOF analysis was applied to MODISSST monthly time series of 2002-2016. This analysis reveals that the three first EOFs
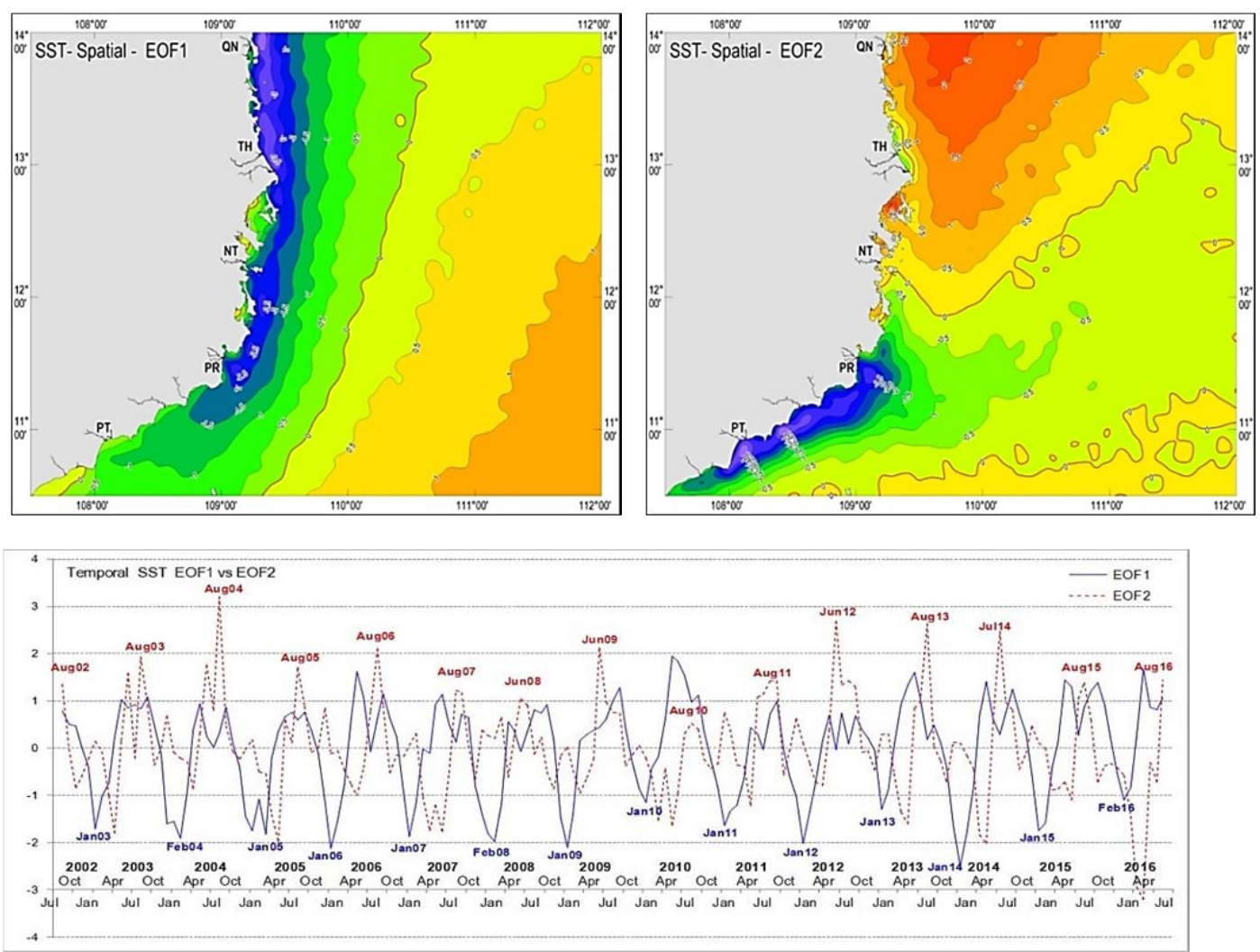

Figure 3. The spatial SST distribution of $\mathrm{EOF}_{1}$ and $\mathrm{EOF}_{2}$ (upper panel) and temporal SST distribution of $\mathrm{EOF}_{1}$ and $\mathrm{EOF}_{2}$ (lower panel)

account for $55.48 \%$ of the total variability, with explained variance of $38.82 \%, 10.01 \%$, and $6.66 \%$, regarding $\mathrm{EOF}_{1}, \mathrm{EOF}_{2}, \mathrm{EOF}_{3}$, respectively. Figure 3 shows spatial and temporal features of $\mathrm{EOF}_{1}$ and $\mathrm{EOF}_{2}$, and Figure 4 shows spatial and temporal features of $\mathrm{EOF}_{3}$. 


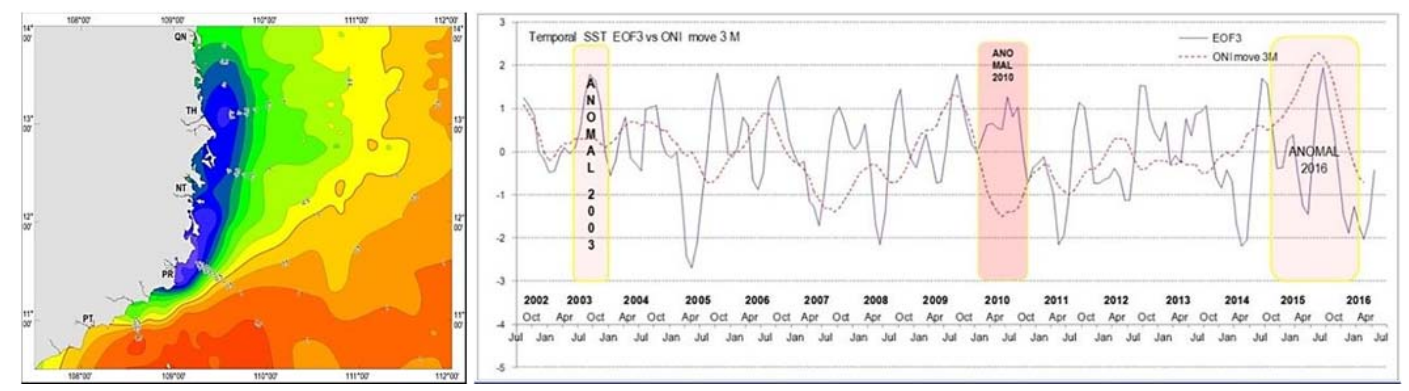

Figure 4. The spatial SST distribution of $\mathrm{EOF}_{3}$ (left panel) and temporal distribution of $\mathrm{EOF}_{3}$ together with $\mathrm{ONI}$ index lag 3 months (right panel)

Results show that the first spatial $\mathrm{EOF}_{1}$ characterizes the intrusion of a cold water mass from North (i.e from Luzon strait (Qu et al., 2004) during North-East monsoon, whereas the spatial $\mathrm{EOF}_{2}$ is typical of the South Vietnam upwelling phenomena with a center of lowest temperature appearing in latitude $11^{\circ} \mathrm{N}$ during South-West monsoon (Le Phuoc Trinh and others, 1981; Vo Van Lanh et al., 1995; Pohlmann, 1987; Shaw and Chao, 1994; Kuo et al., 2000). These results are in agreement with previous studies of Son and Lanh, who also examined the major features of temperature patterns in the whole East Sea from an EOF analysis based on U.S. N vy's Modular Ocean Data Assimilation System (MODAS) data (Tong Phuoc Hoang Son and Vo Van Lanh, 2005). The temporal EOF 1 evolution shows that January is the typical period of the intrusion of cold water mass, while the temporal evolution and spatial distribution of $\mathrm{EOF}_{2}$ show that the strongest upwelling activity usually occurs in August with a strong contrast between the upwelling area and the hot SST background over the studied region in this season. Our conclusions presenting August as the typical month for upwelling phenomena in the Central Vietnam region differ from previous discussions of Le Phuoc Trinh (Le Phuoc Trinh et al., 1981), and Vo Van Lanh (Vo Van Lanh et al., 1995), who suggested that July was the characteristic month for upwelling activity in this region.
Finally, the spatial distribution of $\mathrm{EOF}_{3}$ shows the appearance of SST anomalies associated with the extreme increasing of background SST in the studied region as well as the northward displacement of the cold upwelling-generated centroid (Figure 4). We obtain a strong correlation $(\mathrm{r} 2=0.65)$ between the temporal evolution of $\mathrm{EOF}_{3}$ and Oceanic Niño Index (ONI) with a phase lag of about 3 months (Figure 4). These results agree with previous discussions on anomalies of oceanographic fields over the western edge of East Sea in summer of 1998, 2003, 2010 (years following El-Niño events) under ENSO influence (Qu et al., 2004; Xie et al., 2007, Chung and Long, 2016): during the years when El Niño occur, SST in the ES is strongly increasing and reaches a peak in May of the next year declining El Niño episode. This peak occurs three months earlier as the upwelling which usually occurs in August. Finally, our results also allow us to add summer 2016 to the list of those SST anomalies related to ENSO event.

\subsection{Anomalies of oceanographic structures in mid-summer of El Niño declining episode in East Vietnam Sea coastal waters}

3.2.1. Surface oceanographic anomalies during El Niño episodes

Monthly variability of SST in upwelling center $\left(109^{\circ} 15^{\prime} \mathrm{E} ; 11^{\circ} 15^{\prime} \mathrm{N}\right)$ obtained from 
AVHRR-MODIS image series (1997-2015) showed that, SST summers 1998 and 2010 were about $1^{\circ} \mathrm{C}$ higher than SST for other summers (Figure 5).

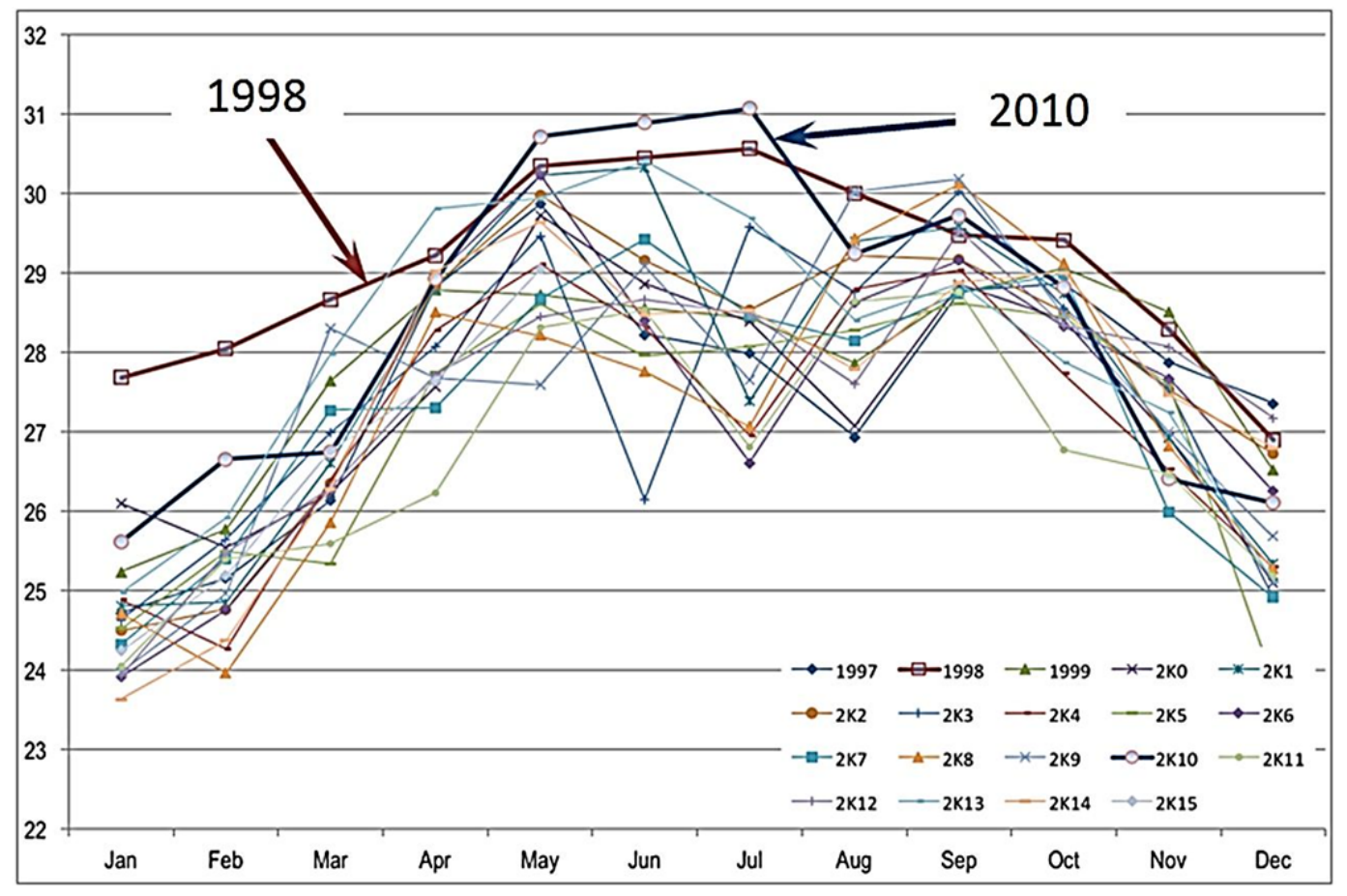

Figure 5. Time series of monthly SST for years from 1997 to 2015 in the upwelling center $\left(109^{\circ} 15^{\prime} \mathrm{E} ; 1^{\circ} 15^{\prime} \mathrm{N}\right)$

Using SST derived from AVHRR and MODIS images, we also identified SST anomalies and a northward moving trend of cold water jet and the disappearance of cold upwelling generated waters occurred during mid-summer of 1998, 2010 and 2016 in comparison with summers of 1997, 2009 and 2015 years (Figure 6). The analysis of the chlorophyll-a distribution in mature and decline phases of El Niño events derived from SeaWiFS/MODIS images gives us similar results (Figure 7). These results once again confirm that SST and Chlorophyll-a anomalies occurred during mid-summer of 1998, 2010 and 2016, coinciding with the decline phase of ENSO.
Recent analysis of surface water circulation system in Vietnamese region (Bui Hong Long, Tran Van Chung, 2015) also showed the northward moving trend of the current dipole for mid-summer of 1998 and its complete disappearance for mid-summer of 2010 (Figure 8). On the contrary, during summers of normal years, surface water circulation in upwelling waters was characterized by the existence of a cold centroid in $11^{\circ} \mathrm{N}$ latitude and by the eastward moving of the cold water tongue (Bui Hong Long, Tran Van Chung, 2015). Those findings confirm the conclusions of previous author (Xie et al., 2003; Kuo et al., 2000) on the strong relationship between the anomalies of oceanic current system and El Niño events in South Vietnam upwelling waters. 
Tong Phuoc Hoang Son, et al./Vietnam Journal of Earth Sciences 39 (2017)

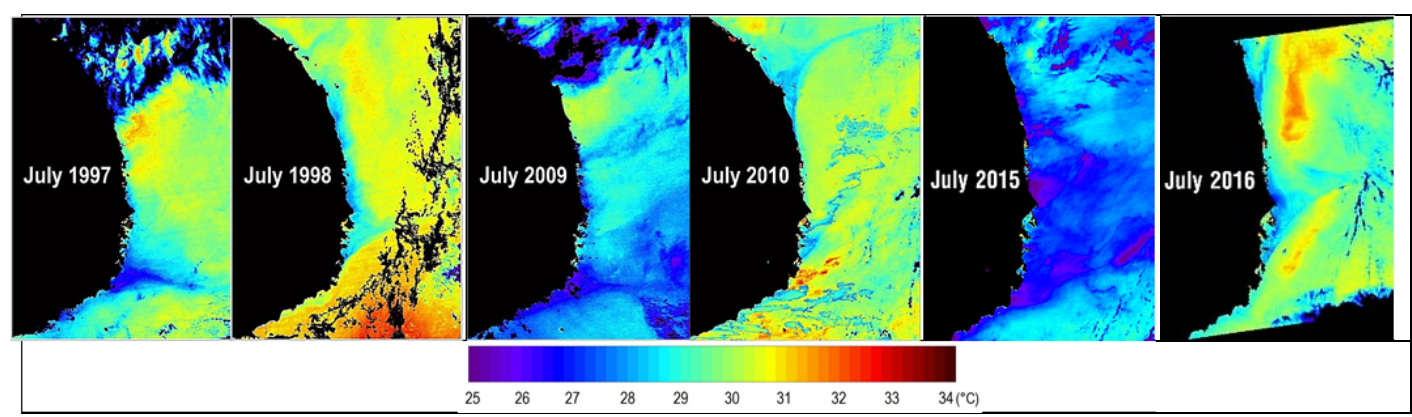

Figure 6. SST distribution in coastal waters of Central of Vietnam Sea during mid summer of regular years (1997, $2009,2015)$ and anomalous years $(1998,2010,2016)$

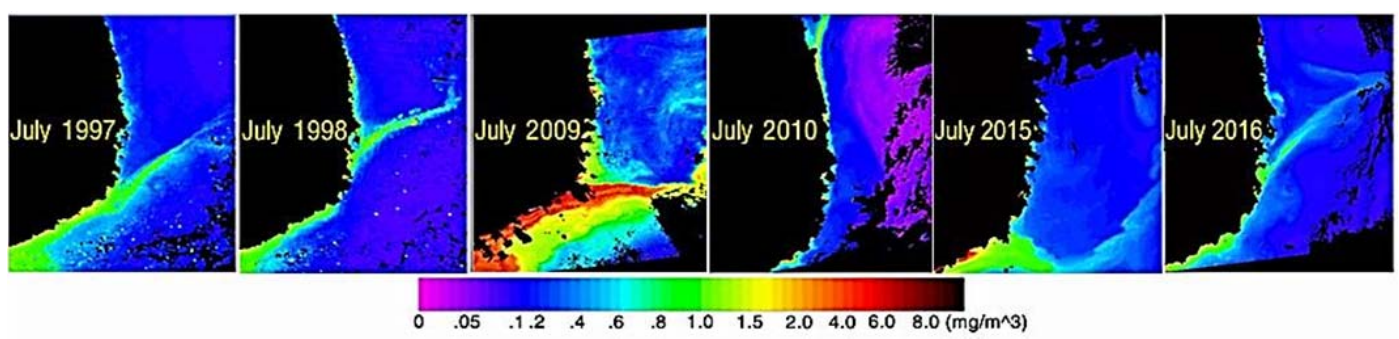

Figure 7. Chlorophyll-a distribution in coastal waters of Central of Vietnam sea during mid summer of regular years $(1997,2009,2015)$ and anomalous years $(1998,2010,2016)$

\subsubsection{Wind Stress Curl anomaly}

Wind stress curl - WSC - is typical of Ekman pump or upwelling generated force in coastal waters under the effects of wind and shore topography (Sverdrup et al., 1942). The spatial distribution of wind field and WSC for July of 1998, 2010, 2014 and 2015 in South Vietnam waters is presented in Figure 9.

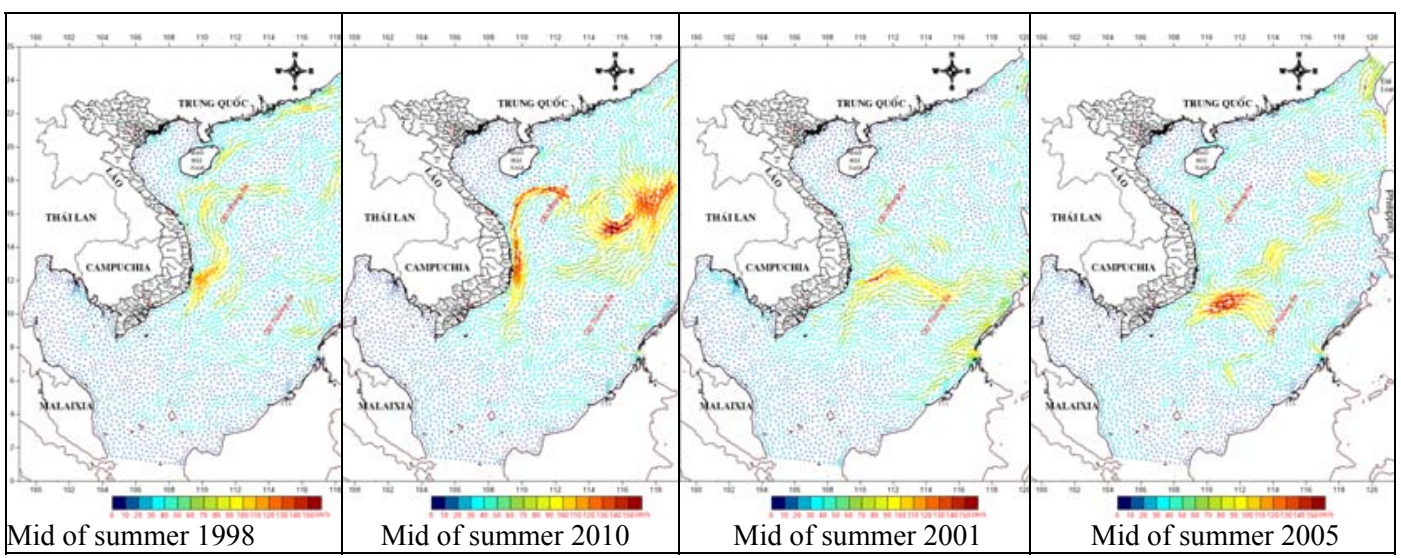

Figure 8. Surface water circulation in mid-summer of 1998, 2010, 2001, 2005 (reconstructed and cited from Bui Hong Long and Tran Van Chung, 2016)

It allows us understanding more into details the disappearance or weakening of upwelling phenomena during El Niño decline phase shown above. The post El Niño accu- 
mulation of heat during a long time induces the thermal base in the land to be much higher than the sea water temperature, due to the large difference of specific heat between earth and sea areas). This is the main reason for the pressure difference between land and sea, that results in the formation of "breeze wind" toward the land. This breeze wind weakens the amplitude strength of southwest monsoon and/or induces a change in wind direction from southwestward to northward.

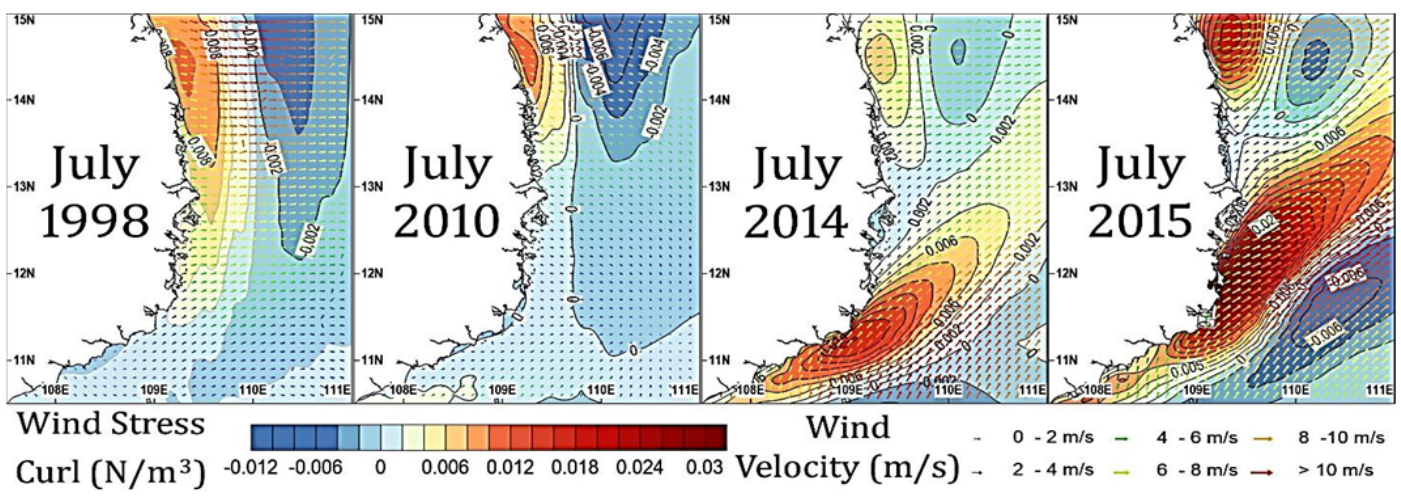

Figure 9. Spatial distribution of wind (color arrows) and wind stress curl (color patterns) for July 1998, 2010, 2014 and 2015 in South Vietnam waters derived from NCEP data

\subsection{Intra-seasonal variations of SST and wind during ENSO episodes}

Figure 10 shows time-latitude hoevmuller graphs of wind speed and SST along $110^{\circ}$ $30^{\prime} \mathrm{E}$, a longitude that crosses the cold-water tongue associated with upwelling waters. For 2014 and 2015, every summer from May to September, there are two to three cooling centers. Each one is associated with a strong basin wide wind pulse $(>8 \mathrm{~m} / \mathrm{s})$ and a temperature drop of at least $1^{\circ} \mathrm{C}$ to $1.5^{\circ} \mathrm{C}$. For summers following the major El Niño events of 1997-1998 and 2009-2010 (i.e. during El Niño decline phase) the entire studied region is abnormally warm, the wind is low and the cold water tongue does not develop eastward (1998) or disappears completely (2010). These results fit well the results of Xia et al. (2007), who examined the intra-seasonal variability of SST and the wind in the relationship with ENSO events during the summers of 1998, 1999, 2003, 2004 along $111^{\circ} 00^{\prime} E$.

\subsection{Thermo-haline structure and water cir- culation of deep layers of Vietnam upwelling waters under the influence of EI Niño event}

In previous sections, we have analyzed into details the anomalous features in surface water at mid-summer in relation with El Niño event. What are the oceanographic characteristics of the deep-sea layers at the same time? We examine this question in the next section through water mass analysis as well as assessment of sea current characteristics along meridian and zonal sections.

3.4.1. Deep layers thermo-haline characteristics at midsummer resulting from water masses analysis

Classical TS water mass analysis combined with Cluster analysis from assimilation $\mathrm{HYCOM} / \mathrm{NCODA} / \mathrm{FEM}$ data, allow us to identify four main water masses with clearly distinguished characteristics for anomalous years (i.e. under El Niño effect, as 
Tong Phuoc Hoang Son, et al./Vietnam Journal of Earth Sciences 39 (2017)

July 1998, 2010) compared to water masses characterstics for normal years (i.e, July 2014, 2015). The division of water masses of the mid summer of 1998, 2010, 2014, 2015 is shown into details in Table 1.

Results show that, temperature of surface water layers in post El Niño midsummer abruptly increases (about $1-2^{\circ}$ ) in comparison with temperature in normal periods. Temperature in surface layers in July 1998 and 2010 reaches $30.8^{\circ} \mathrm{C}$, whereas in July of 2014 and 2015 , it is only about $28.8^{\circ} \mathrm{C}$. The thickness of TS scatterplots along the vertical axis (Figure 11) is used to determine the homogeneous or non-homogeneous aspects of thermo-haline layer as well the ability of water masses to exchange across the different layers. Water salinity is relatively uniform for post El Niño periods (ie. mid summers of 1998 and 2010), with a fluctuation range for upper water layers varying between 31.5 and 34.5 psu. Whereas, during normal years (e.g. summers of 2014, 2015), this range is larger,
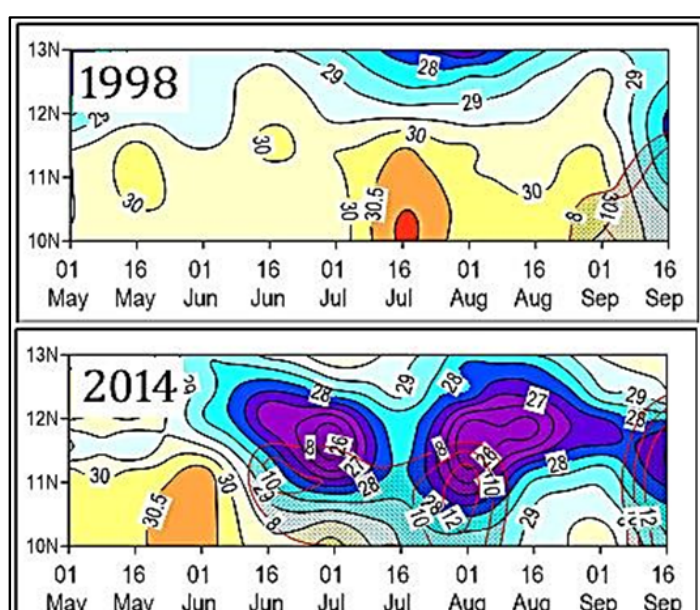

varying between 30.0 and 35.5 psu. This allows us to conclude that during abnormal years under the infuence of El Niño, water exchange along vertical direction (from bottom to surface) is very limited and deep, high salinity water masses are not transported upward to shallower as well as surface layers".

The 3D volume plot obtained from cluster analysis of HYCOM/NCODA/FEM data (Figure 12), provides us a visual picture of the distribution and movement of water masses. Analysed results show that in post El Niño periods, thermo-haline stratification direction is alongshore and creates a dominant northward current system in whole water collumn from surface to $50 \mathrm{~m}$ depth. Upwelling phenomenon weakened or almost completely disappeared in mid summers of 1998 and 2010 during El Niño decline phase. On the contrary it appeared clearly in July 2014 and July 2015.
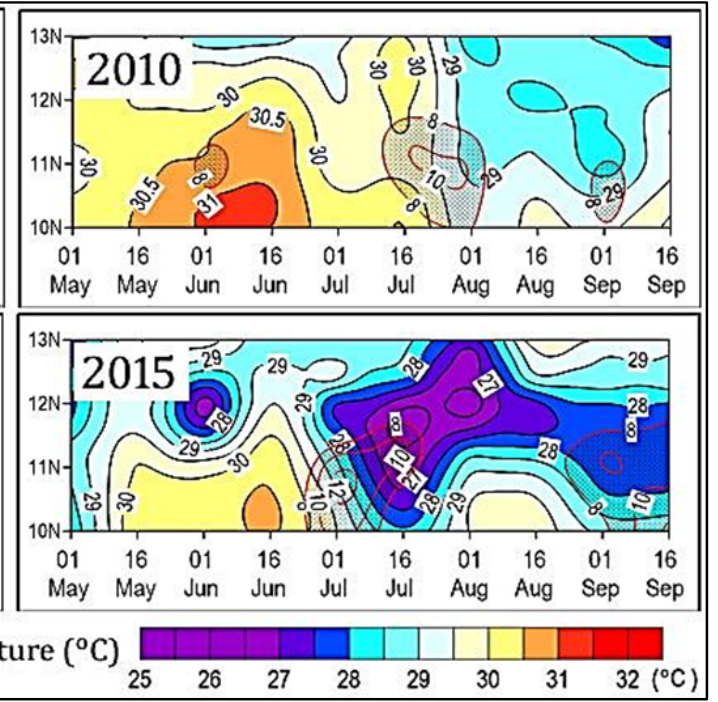

Figure 10. Summer intra-seasonal pulses observed on time-latitude hoevmuller graphs of SST $\left({ }^{\circ} \mathrm{C}\right.$, color shading) and wind speed (m/s, gray pattern) at $109^{\circ} 30^{\prime} \mathrm{E}$ for the summers (May to September) of (a) 1998, (b) 2010, (c) 2014, and (d) 2015 
Vietnam Journal of Earth Sciences, 39(3), 225-239

Table 1. Repartition of water masses Cluster analysis of HYCOM/NCODA/FEM data for July 1998, 2010, 2014, 2015

\begin{tabular}{|c|c|c|c|c|c|}
\hline & Water Masses & Deep layer (m) & Temperature $\left({ }^{\circ} \mathrm{C}\right)$ & Salinity (\%) & Water density (sigma t) \\
\hline \multirow{8}{*}{ Year of 1998} & Water Mass A & $0-90$ & $20.9-30.5$ & $28.7-34.4$ & $15.6-33.3$ \\
\hline & & & 28.6 & 33.4 & 21.0 \\
\hline & Water Mass B & $0-100$ & $20.3-27.0$ & $32.5-34.0$ & $15.3-20.4$ \\
\hline & & & 25.3 & 33.3 & 18.2 \\
\hline & Water Mass C & $40-150$ & $14.9-27.3$ & $33.7-34.7$ & $10.7-20.8$ \\
\hline & & & 18.6 & 34.4 & 13.4 \\
\hline & Water Mass D & $200-500$ & $7.8-15.8$ & $34.4-34.6$ & $5.4-11.9$ \\
\hline & & & 11.5 & 34.5 & 8.4 \\
\hline \multirow{10}{*}{ Year of 2010} & Water Mass A & $0-80$ & $19.2-31.0$ & $18.7-34.2$ & $9.4-24.3$ \\
\hline & & & 29.0 & 33.0 & 20.6 \\
\hline & Water Mass B & $20-100$ & $19.6-30.5$ & $32.7-34.4$ & $20.1-24.3$ \\
\hline & & & 26.4 & 33.8 & 22.0 \\
\hline & Water Mass C & $25-125$ & $14.4-24.3$ & $33.5-34.7$ & $22.8-25.7$ \\
\hline & & & 19.1 & 34.3 & 24.4 \\
\hline & Water Mass D & $80-150$ & $13.4-18.2$ & $34.4-34.7$ & $24.4-26.0$ \\
\hline & & & 15.8 & 34.5 & 25.4 \\
\hline & Water Mass E & $200-500$ & $8.0-15.3$ & $34.4-34.7$ & $25.5-26.8$ \\
\hline & & & 11.9 & 34.5 & 26.1 \\
\hline \multirow{10}{*}{ Year of 2014} & Water Mass A & $0-50$ & $28.1-30.3$ & $25.6-31.2$ & $15.2-19.1$ \\
\hline & & & 28.4 & 29.1 & 17.8 \\
\hline & Water Mass B & $0-70$ & $25.1-32.2$ & $30.9-34.1$ & $18.9-22.1$ \\
\hline & & & 28.2 & 33.1 & 20.9 \\
\hline & Water Mass C & $50-100$ & $24.9-32.4$ & $31.4-34.2$ & $18.8-22.2$ \\
\hline & & & 27.7 & 33.0 & 21.0 \\
\hline & Water Mass D & $0-125$ & $17.2-20.9$ & $31.1-35.8$ & $21.7-25.2$ \\
\hline & & & 22.5 & 34.3 & 23.5 \\
\hline & Water Mass E & $150-500$ & $8.0-18.7$ & $34.2-35.6$ & $24.7-26.9$ \\
\hline & & & 13.5 & 34.3 & 26.0 \\
\hline \multirow{8}{*}{ Year of 2015} & Water Mass A & $0-50$ & $26.4-28.8$ & $25.6-31.9$ & $15.2-20.6$ \\
\hline & & & 28.2 & 29.9 & 18.5 \\
\hline & Water Mass B & $0-100$ & $18.6-28.9$ & $31.7-34.2$ & $19.7-20.1$ \\
\hline & & & 26.4 & 32.9 & 21.3 \\
\hline & Water Mass C & $0-100$ & $17.4-29.8$ & $33.4-35.8$ & $20.8-25.7$ \\
\hline & & & 25.3 & 34.2 & 22.6 \\
\hline & Water Mass D & $125-500$ & $8.2-20.2$ & $34.3-35.6$ & $24.5-27.0$ \\
\hline & & & 13.8 & 34.6 & 25.9 \\
\hline
\end{tabular}

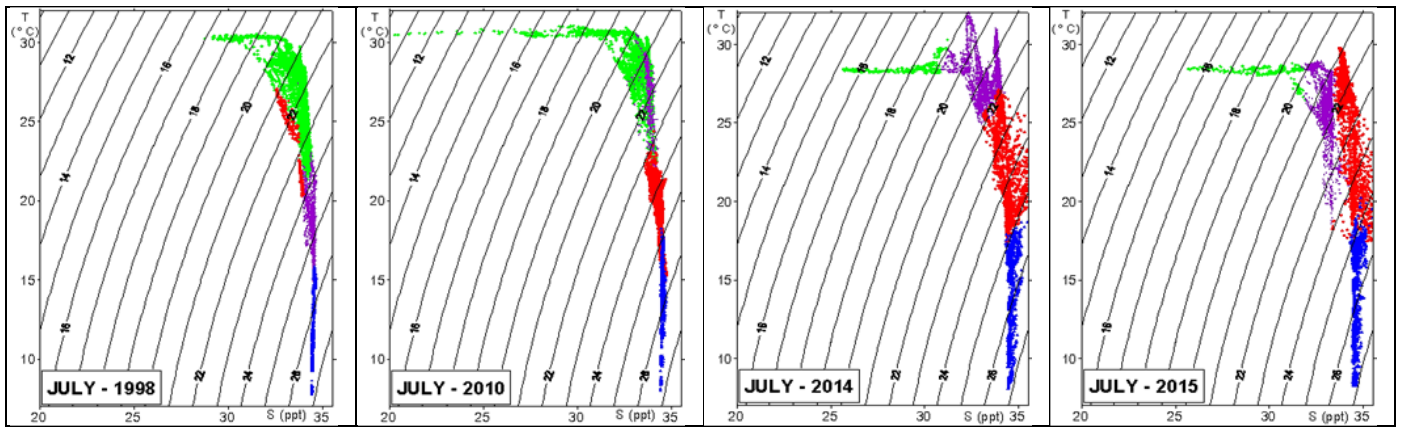

Figure 11. TS diagrams of HYCOM/NCODA/FEM data for July 1998, 2010, 2014 and 2015 
Tong Phuoc Hoang Son, et al./Vietnam Journal of Earth Sciences 39 (2017)

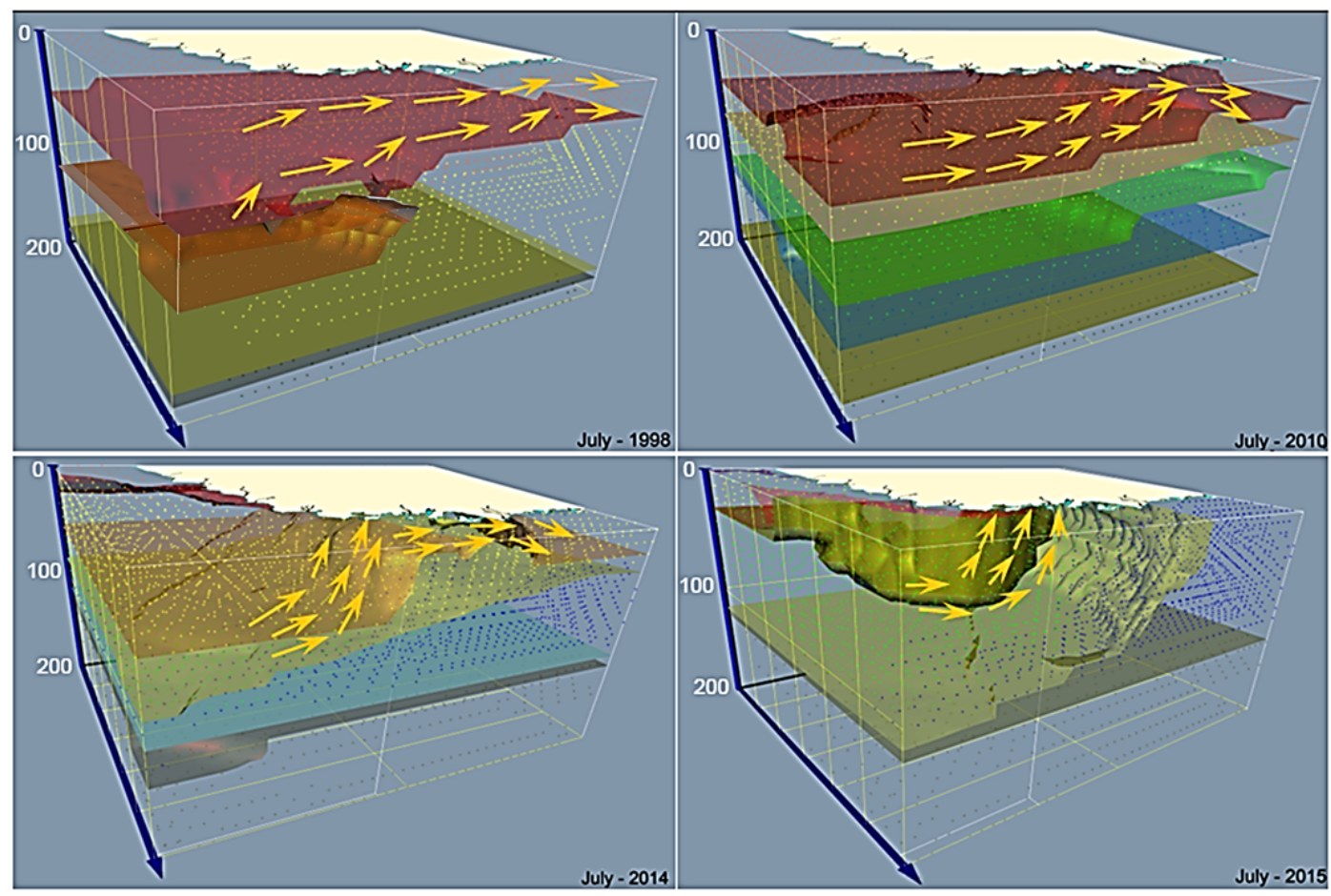

Figure 12. 3D volume plot presenting transport water masses in beneath the sea surface in South Vietnam upwelling coastal waters sea from cluster analysis during mid-summers 1998, 2010, 2014 and 2015, from

HYCOM/NCODA/FEM data

3.4.2. Thermo-cline layer depth in South Vietnam upwelling center under the influence of ENSO and global warming

From the analysis of temperature and salinity profiles in upwelling center $\left(109^{\circ} 00 \mathrm{E}\right.$; $11^{\circ} 15^{\prime} \mathrm{N}$, Figure 12), we can distinguish three patterns of temperature-salinity profiles in the relationship with the depth of thermocline layer: the first profile (Figure 13, left) characterizes the normal situation with a thermohalocline layer between 35 and $40 \mathrm{~m}$ depth. Weak influence of relatively cold water is the main reason responsible for the creation a shallow thermocline layer. The second profile (Figure 13, middle) characterizes the $1^{\text {st }}$ anomaly profile with a thermo-halocline layer between 50 and $60 \mathrm{~m}$ depth. The discussion of $\mathrm{Qu}$ et al. (2004) showed that "SST in the ES increases around the mature phase of El Niño and reaches a peak in the following summer" suggesting that extremely warm sea water during El Niño episodes (i.e., 1998, 2003) pressing the thermo-halocline layer downward is the main factor responsible for the above phenomenon. Moreover, analyzed results also show that sea water temperature gradually increasing during the period 2008-2012 intensified above phenomena, participating in pushing the thermo-halocline layer deeper.

The third profile (Figure 13, right) characterizes a new recent anomaly with the thermohalocline layer between 90 and $100 \mathrm{~m}$ depth. Extreme global warming in recent years from 2012 to 2016 indeed pressed the thermohalocline layer down to the lowest level, This process may continuously progress in next years under the influence of global warming. 
Vietnam Journal of Earth Sciences, 39(3), 225-239

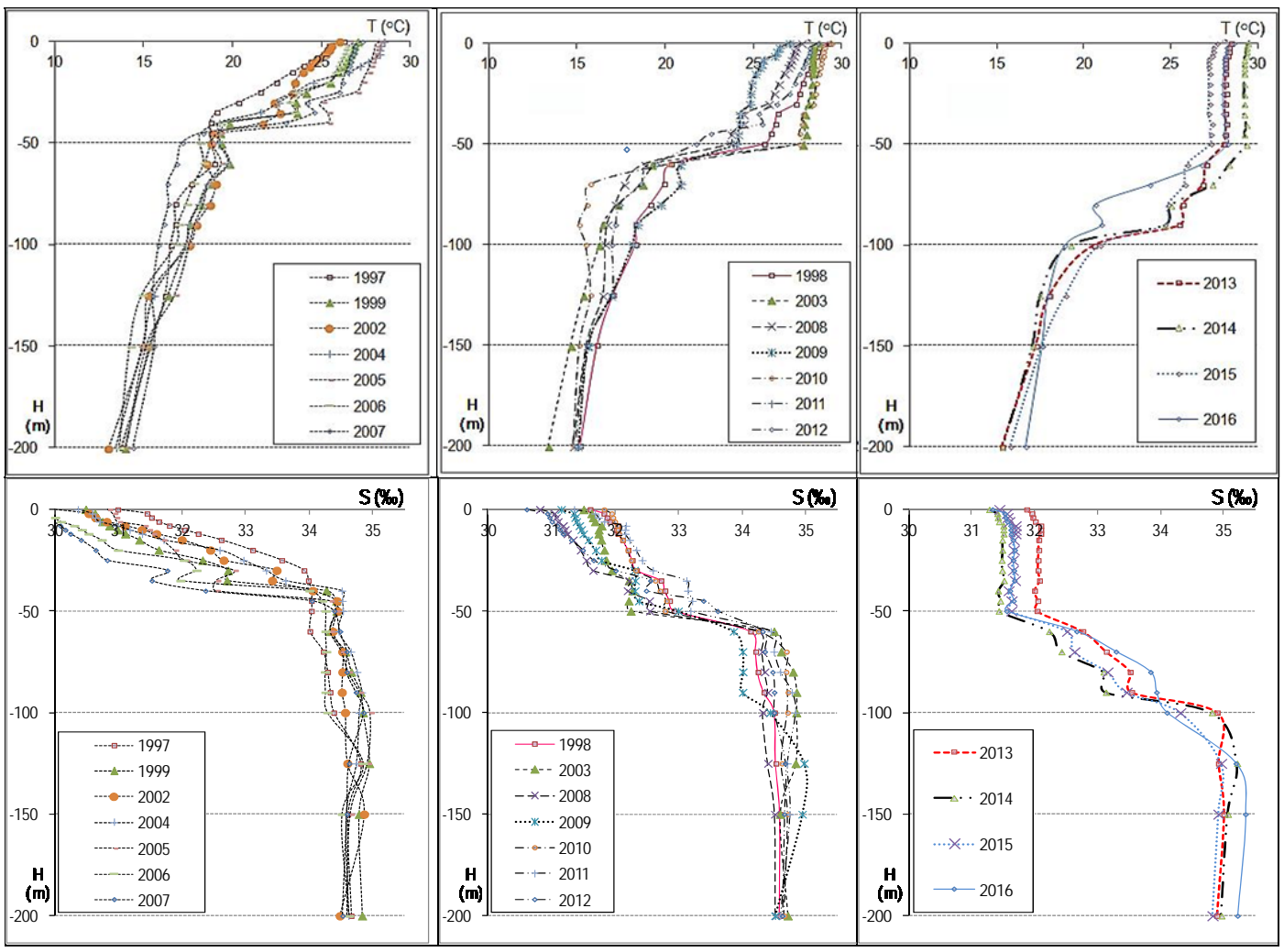

Figure 13. Temperature (above) and salinity (below) vertical profiles in the upwelling centroid $\left(109^{\circ} 00^{\prime} \mathrm{E} ; 11^{\circ} 15^{\prime} \mathrm{N}\right)$ in South of Vietnam Sea from 1997 to 2016. Normal periods (left), periods under the influence of El Niño event combined with a relative sea water temperature rise during the period 2008 - 2012 (middle) and recent years periods with a strong impact of global warming, i.e. 2013 - 2016 (right)

Note that, in analyzing results in Figure 13, we removed temperature and salinity profiles of years 2000 and 2001 which didn't suit with the general rule of a shallow thermocline depth for normal years. These profiles (not shown her) look similar to the $2^{\text {nd }}$ profile pattern corresponding to situations strongly affected by El Niño events. Bui Hong Long and Tran Van Chung (2015) found that the extreme rising of sea water level of 2001 and 2010 was related to a period of strong La Niña event. One could hence wonder if there an influence of La Niña events on the depth of thermo-halocline layer In South Vietnam upwelling area. This question will be addressed in future studies.

\section{Conclusions}

Based on the analysis of temporal and spatial variations of oceanic characteristics derived MODIS image satellite data and of the assimilated data coming from the HYCOM/NCODA system coupled with a local Finite Element Model (FEM), the oceanic anomalies in South Vietnam upwelling waters submitted to the influence of ENSO events were examined into details. Abnormal oceanography features appear mainly for the summers of 1998, 2003, 2010 and 2016 years during El Niño decline phase.

The weakening of upwelling during El Niño decline episodes appears through the following abnormal signals: 
Tong Phuoc Hoang Son, et al./Vietnam Journal of Earth Sciences 39 (2017)

- Wind force and upwelling generated Ekman pump are very weak.

- The cold saline tongue is shifted northward but not extended eastward.

- Sea water circulation in both surface and deeper water layers were dominantly northward.

- The depth of thermocline layer in South Vietnam upwelling center is deeper (about 90 $-100 \mathrm{~m}$ ) for post-El-Niño summers in comparison with pre-El-Niño and normal years (50$60 \mathrm{~m}$ and 35-40 $\mathrm{m}$, respectively).

Some new finding is obtained from this study:

- Typical months of South Vietnam upwelling phenomena is August and not July;

- During the years when El Niño occurs, sea surface temperature strongly increases and reaches a peak during May of El Niño decline episode during the next year;

- Extreme ocean warming in recent years, i.e 2012-2016, pressed the thermo-halocline layer in upwelling center during summer down deeper, i.e. in 90-100 $\mathrm{m}$ deep. This process associated with the influence of the global warming may progress continuously, inducing the thermo-halocline layer to become deeper and deeper during next years.

\section{Acknowledgements}

This article is a part of research results of the institutional basic research project-2017 funded by Institute of Oceanographythe Vietnam Academy of Science and Technology (IO-VAST). Thanks to Professor Joji Ishizaka, Dr Eko Siswanto and other members of APN project with code CAF2015-RR11-NMY-Siswanto for discussions and exchanging on scientific information before publishing this article. The authors would like to thank their colleagues of the Center on Marine database GIS and Remote Sensing Center for collaborating and helping in the process of completing this work.

\section{References}

Barthel K., Rosland R., and Thai N.C., 2009. Modelling the circulation on the continental shelf of the province Khanh Hoa in Vietnam, J. Mar. Syst., 77(1-2), 89-113.

Bui Hong Long, Tran Van Chung, 2009. Calculations of currents in the upwelling region along south-central Vietnamese coast, using three dimensions (3-D) nonlinear model", Journal of Marine Science and Technology - VAST, 9(2), 01-25 (in Vietnamese).

Bui Hong Long, Tran Van Chung, 2017. Preliminary studies on the impact of climate change on the upwelling region south Central Vietnam in summer. Journal of Marine Science and Technology - VAST, 17(1), 01-19 (in Vietnamese).

Colling A., 2001. Ocean Circulation, Open University Course Team. Second Edition. ISBN 978-0-75065278-0.

Dippner J. W., and Loick-Wilde N., 2011. A redefinition of water masses in the Vietnamese upwelling area, $\mathrm{J}$. Mar. Syst., 84(1-2), 42-47.

Hale W.G., Margham J.P, and Sauder V.A., 2005. Collins Dictionary of Biology $3^{\text {rd }}$. London: Collin.

Huang Q.-Z., W.-Z. Wang, Li Y.S., and Li C.W., 1994. Current characteristics of the South China Sea, in Oceanology of China Sea, edited by D. Zhou, Y.-B. Liang, and C.K. Tsebgm, 39-47, Kluwer Acad., Norwell, Mass.

Hurlburt H.E., Chassignet E.P., Cummings J.A., Kara A.B., Metzger E.J., Shriver J.F., Smedstad O.M., Wallcraft A.J., and Barron C.N., 2008. Eddyresolving Global Ocean Prediction, in M. Hecht and H. Hasumi, eds., Ocean Modeling in an Eddying Regime, Geophysical Monograph 177 (American Geophysical Union, Washington, DC).

Knauss J.A., 2005. Introduction to Physical Oceanography, Waveland Press. Second Edition. ISBN 978-157766-429-1.

Kuo N.J., Zheng Q., Ho C.R., 2004. Response of Vietnam coastal upwelling to the 1997-1998 ENSO event observed by multisensor data, Remote sensing of Environment, Volume 89, Issue 1, 15 January, 106-115.

Le Phuoc Trinh, Nguyen Tien Dung, Nguyen Van Minh, Le Minh Tan, Nguyen Kim Vinh, 1981. A proposal 
Vietnam Journal of Earth Sciences, 39(3), 225-239

of studies on the upwelling of Southeastern coast of Vietnam, Collection of Marine Research Works, 2(2), 13-31 (in Vietnamese).

Nguyen Van Long and Vo Si Tuan, 2010. Status of coral reefs in Vietnam following the 2010 coral bleaching event. In: Kimura T, Tun K (eds) Status of Coral Reefs in East Asian Seas Region: Ministry of the Environment, Japan, 29-49.

NOAA National Centers for Environmental Information, State of the Climate: Global Analysis for Annual 2010, published online January 2011, retrieved on March 25, 2017 from http://www.ncdc.noaa.gov/sotc/global/201013.

Ose T., Song Y., and Kitoh A., 1997. Sea surface temperature in the South China Sea: An index for the Asian monsoon and ENSO system, J. Meteorol. Soc. Japan., 75, 1091-1107.

Pohlmann T., 1987. A three dimensional circulation model of the South China Sea., 245-268. In ThreeDimensional Models of Marine and Estuarine Dynamics, ed. by J. J. Nihoul and B. M. Jamart, Elsevier, New York.

Qu T., Kim Y.Y, Yaremchuk M., Tozuka T., Ishida A., Yamagata T., 2004. Can Luzon strait transport play a role in conveying the impact of ENSO to the South China Sea, J. Clim. 17, 3644-3657.

Shaw P.T., and Chao S.Y., 1994. Surface Circulation in the South China Sea, Deep-Sea Res., I(41), 1663-1683.

Siswanto E., Ye H., Yamazaki D., and Tang D.L., 2017. Detailed spatiotemporal impacts of El Niño on phytoplankton biomass in the South China Sea, J. Geophys. Res. Oceans, 122, doi:10.1002/2016JC012276.

Sverdrup H.U., Johnson M.W. and Fleming R.H., 1942. The Oceans: their physics, chemistry and general biology. Prentice Hall, New York, 1087p.

Tang D. L., Kawamura H., H. Doan Nhu, and Takahashi W., 2004. Remote sensing oceanography of a harmful algal bloom off the coast of southeastern Vietnam, J. Geophys. Res., 109, C03014, doi:10.1029/2003JC002045.
Thai Minh Quang, 2016. Studies on influence of 2016. El Niño event to coral bleaching phenomena in coastal waters in Ninh Hai - Ninh Thuan province. Technical report of basic research project funded by Institute of Oceanography - the Vietnam Academy of Science and Technology (in Vietnamese).

Tong Phuoc Hoang Son, Vo Van Lanh and Lau Va Khin, 2005. Application of empirical orthogonal function (EOF) for studying thermal structure in sea surface water in South China Sea. The $26^{\text {th }}$ Asian Remote sensing Conference, 7-11 November 2005 in Hanoi.

Tran Van Chung, Bui Hong Long, 2016. Effect of temperature field and anomalies of sea water level in East Vietnam Sea in relationship to global climate change - Journal of Marine Science and Technology - VAST, 16(3), 255-266 (in Vietnamese).

Vo Van Lanh, 1995. The environmental characteristics of strongly upwelling waters in south of Vietnam and its ecological impacts. Technical report of National project KT03.05. Institute of Oceanography, 480 p (in Vietnamese).

Vo Si Tuan, 2000. The corals at Con Dao archipelago (South Vietnam): before, during and after the bleaching event in 1998. In: Proceeding of $9^{\text {th }}$ International Coral Reef Symposium, Bali, Indonesia, $23^{\text {rd }}-27^{\text {th }}$ October, 895-899.

Wang B., An S., 2005. A method for detecting seasondependent modes of climate variability: S-EOF analysis. Geophys. Res. Lett., 32, L15710.

Wyrtki K., 1961. Physical oceanography of the Southeast Asian waters, Naga Rep. 2, 195p, Scripps Inst. of Oceanogr., La Jolla, Calif.

Xie S.-P., Xie Q., Wang D. and Liu W.T., 2003. Summer upwelling in the South China Sea and its role in regional climate variations, J. Geophys. Res., 108(C8), 3261, doi:10.1029/2003JC001867.

Xie S.-P., Chang C.-H., Xie Q. and Wang D., 2007. Intraseasonal variability in the summer South China Sea: Wind jet, cold filament, and recirculations, J. Geophys. Res., 112, C10008, doi:10.1029/2007JC004238. 